\title{
ПЕРИОДИЗАЦИЈЕ СРПСКЕ И ЈУГОСЛОВЕНСКЕ КЬИЖЕВНОСТИ ПАВЛА ПОПОВИЋА С ОБЗИРОМ НА ОДРЕЪЕЮЕ СТАРЕ СРПСКЕ КЬИЖЕВНОСТИ
}

\begin{abstract}
У овом раду испитујем ,историјску критику” нашег истакнутог историчара књижевности као методолошко полазиште за његово разматрање периода српске и југословенске литературе, а пре свега за његово одређење старе српске књижевности као њихове зачетне фазе. Непосредни циљ овог истраживања је да се са литерарноестетског становишта као темељног за једну историју књижевне форме провери веродостојност Поповићеве периодизације старе српске литературе. Утолико се посебно занимам за његово генеричко дефинисање ове књижевности.

Кључне речи: историјска/естетска/генеричка критика, критика средине/момента, периодизација, (стара, средњовековна) српска/југословенска књижевност, историја књижевне форме.
\end{abstract}

Свој Преглед српске књижевности објавио је Павле Поповић 1909. као плод властитог петогодишњег наставничког рада (Поповић 1999a: 1) на Великој школи од 1904. и Универзитету у Београду од 1905. године. У поднаслову је тачно назначио предмет свог историјског Прегледа (Пантић 1999: 227) ограниченог на Стару, односно српску средњовековну, на Народну, тј. усмену књижевност различитих времена код Срба, и на Дубровачку књижевност, стварану на српском, штокавском наречју од краја 15, па до краја 18. столећа у овом приморском граду-републици. Павле Поповић је 1904. изабран у звање ванредног професора за Српску књижевност заједно са Јованом Скерлићем, с којим је потом делио тај предмет, тако што је овај држао предавања из Историје нове српске књижевности, о којој је објавио монографију најпре у средњошколском, скраћеном издању 1912, а потом и њену целовиту, академску верзију 1914. године. Рад ове двојице колега узајамно се допуња-

*mloma@fil.bg.ac.rs 
вао не само на Филозофском факултету (Милосављевић 1994: 343; Павловић 1959: 203), него и кроз сарадњу на Српском књижевном гласнику. Након Скерлићеве преране смрти, Поповић је после Великог рата „морао дуго година да одржава са̂м наставу целокупне наше књижевности”, па је своју предавачку пажњу посветио „поглавито писцима наше нове књижевности - Доситеју, Бранку Радичевићу, Змају, Ђури Јакшићу и другима” (Павловић 1959: 204). Још за време рата, учествујући у раду лондонског Југословенског одбора написао је и у Кембриџу почетком 1918. године објавио Југословенску кюижевност, од чије концепције није одустајао до краја свог живота 1939. године, разрађујући је још у два значајна маха: најпре 1922. у својој приступној беседи у Српској краљевској академији са темом Југословенска књижевност као ичелина, па опет 1930. у студији на француском језику La littérature Yougoslave (преведено 1934. као Оглед о југословенској књижевности) (Љубинковић 1999: 208; Николић 2009: 267-268), да би напокон у својим последњим годинама приступио изради обимних студија као саставног дела једне интегралне и потпуне историје југословенске књижевности, за коју је стигао да напише првих десет поглавља. Од тог позног рада остали су и значајни одељци посвећени управо старој српској књижевности (Павловић 1959: 206), што само сведочи о њеној важности за успостављање периодизацијске концепције не само српске, него и југословенске књижевности, jep је средњовековна литература код Срба, по Поповићевом мишљењу, била и највише достигнуће истовремене литературе код Југословена (Поповић 1999б: 4).

У свом Прегледу српске књижевности Поповић је излагање почео од њеног постања, отприлике средином 12. века, са јављањем српске рецензије старословенског језика (Поповић 1999а: 2). Затим је утврдио усмено истрајавање поезије и прозе на српском говорном језику код простог, неписменог народа, као и њихов поновни улазак у писмени израз на српској штокавштини код образованих племића и грађана Дубровачке републике. Тако је српска старија књижевност подељена на три готово сасвим одвојене литературе, које унеколико следе једна за другом, али без неке значајније узајамне повезаности, чиме је аутор антиципирао Скерлићеву концепцију књижевних дисконтинуитета у целокупном српском књижевном развоју све до његове најновије фазе, која започиње у 18. веку (Скерлић 2006: 19-23). Идеја дисконтинуираности једне националне литерарне традиције присутна је иначе у ондашњој позитивистичкој историографији, за шта је значајан пример дао Рихард Мориц Мајер (1860-1914) у својој 1916 (постхумно издатој) Историји немачке кьижевности до почетка 19. века (Меyеr 1916: 3-4; Лома 1994: 75-76).

Стара српска књижевност је настала код образованог монаштва у преписима пре свега светих књига за високо племство у Срба (Поповић 1999б: 4), чему је најстарије сведочанство Мирослављево јеванђеље из друге половине 12. столећа (Поповић 1999а: 11). Поповић је везао настанак српске књижевности за „постанак велике, уједињене државе српске” „крајем 12. века” и за образовање Хиландара као ,једног од највећих књижевних средишта српских" (Исто: 13), што је исход Поповићевог приступа путем историјске крити- 
ке књижевности. Тај поступак полази од особености уметничких достигнућа у језику, односно од посебних књижевних вредности, које се успостављају превасходно настанком и развојем књижевних родова и врста у присној повезаности са духовном, односно културном средином и моментом, како локалне, националне, тако и опште европске литерарне традиције. Заправо, из садејства места и тренутка настају књижевне вредности као њихов најприснији израз (Лома 1998: 51-53, 58-62, 68-69).

Тако је, с обзиром на образовну и верску оријентацију ка Византији, утемељењу српске националне књижевности пресудно допринела „византијска књижевност, која је у то време била једна од најјачих у Европи". Из ње су Срби у своју књижевност преузимали већ развијене различите „књижевне и научне” родове, међу којима Поповић посебну пажњу обраћа на „списе који непосредније спадају у праву књижевност” (Поповић 1999 а: 14), на „родове више књижевне”, и на дела у њима која су „књижевно важна” (Исто: 2), односно у којима значајну улогу добија језичкоуметничка тежња поред оне извештајне. Српска поезија тога времена је профана и црквена, али је „има врло мало”. „Скоро сва стара књижевност је у прози” (Исто: 14). И ту, као и у поезији преовлађују преводи, углавном византијске литературе.

Насупрот томе, „биографије српских владалаца и архиепископа, старе српске биографије” представљају „оригиналан рад” као „део хагиографске књижевности”, писане „по угледу на византијску хагиографију” (Исто: 26-27). Како су дела овог књижевног жанра „најбољи представници старог књижевног образовања нашег, а и драгоцени споменици наше прошлости" (Исто: 26), Поповић им посвећује посебну пажњу и излаже њихово генеричко развијање од 13. до 17. века „хронолошким редом” (Исто: 27), слично начину на који ће по столећима представити жанрове дубровачке књижевности, будући да се једино тако, по ауторовом мишљењу, може приказати прави књижевни развој у његовом органском току „раста и опадања”, нестанка и појаве нових књижевних врста (Поповић 1999а: 4-5).

Стару српску биографску књижевност започиње код нас св. Сава пишући као увод у Студенички типик у првим деценијама 13. века своје „најважније”, „иначе малено дело” - Живот св. Симеона, свог почившег оца, великог жупана Рашке Стефана Немање, онако названог у монаштву. Тај мали спис је „после кратког помена о зидању Студенице” усредсређен „на последње године Немањиног живота": од силаска с престола и замонашења у овом манастиру преко његовог монашког живота ту и на Светој Гори, оснивања тамо Хиландара, болести и смрти у овоме до преноса Немањиних моштију у Студеницу. Поповић посебно истиче једноставност Савиног стила и његово реалистичко приповедање, што ће, по мишљењу овог књижевног историчара, потом постати главна одлика старих српских биографија: „Од свију старих биографија наших ова је најмања и најпростија. У њој је најмање реторике, најмање позивања на речи и лица из Библије, најмање чудеса; причање је у њој просто, једро, и садржи где-где лепу слику или нежан пасаж (Исто). 
Штавише, она ту и тамо износи хронолошке податке, за разлику од других дела овога жанра у нас и њихових „византијских узора” (Исто: 28).

Стефан, „први краљ српски” је након свога брата Саве такође у првим десетлећима 13. века написао један Живот св. Симеона, њиховога оца. Будући да је ово, за разлику од Савинога - „засебно дело”, представља оно „прву у правом смислу речи стару српску биографију”. Она је „двапут већа” од оне коју је сачинио Сава, те „обухвата и више момената из Немањиног живота”, који претходе онима у Саве описаним, те „нарочито обухвата” Немањина „чудеса после смрти”, којима овај и мртав штити српску земљу, „и даје им доста места". Стефанова обрада истог предмета је другачија од Савине. Она је ,реторска, китњастија него Савина”, у њој је „и више библијских реминисценција”, и „пуно чудеса и легенди”, што унеколико умањује реалистички утисак ,лепих, живописних и речитих места” (Исто: 28).

За краља Уроша је почетком прве деценије у другој половини 13. столећа монах Доментијан написао у Савиној Карејској ћелији биографију св. Саве, а потом средином наредног десетлећа - ону св. Симеона у Хиландару, задужбини овог светог владара. Живот св. Саве је велико дело, „много веће” од Стефановога, оно је „највећа наша биографија” (исто), која износи све Савине животне моменте (Исто: 28-29). „Живот св. Симеона знатно је мање и неважније дело”, које садржински сасвим одговара Стефановоме закључно са приповедањем о преносу светитељевих моштију, само је у опису „опширније и развученије”, те је и веће од онога. „Доментијанов рад значи напредак у развитку наших биографија”: „његово дело о Сави” је „пуно историјских података, оно је прва наша „потпуна биографија”, будући да Стефанов рад изоставља више важних момената из Немањиног живота. Али оно има и много легендарног материјала, „више него у ранијим делима” (Исто: 29). То му је мана, по Поповићевом мишљењу, а и то што је, као и рад истога писца о Немањи, „препуно позивања на библијске речи и примере, паралела с библијским личностима” или „празних и излишних морално-религиозних разматрања, сваковрсних реторских амплификација које се једнако уплићу у причање, и задржавају га сваки час" (Исто).

Крајем 13. века је хиландарски монах Теодосије прерадио Доментијаново житије св. Саве, но тако да је по обиму само мало мање од овога, и то му је најважније дело поред Похвале св. Симеону и Сави, те Службе овим светитељима. Теодосијева прерада је садржински једнака прерађеном делу, ,али је сва учена реторика” која у овоме

задржава причање - избачена, а место тога је дошло причање чисто, беспрекидно, живо, живописно, са пуно легендарних елемената, додуше, али и те легенде имају своју наивну лепоту. Стилистички и књижевно уопште, ова је биографија најбоља; она је и једно од најбољих дела целе наше старе књижевности (Исто: 30 ).

Чак и „легендарни елементи”, уколико су „живописно”, са смислом за реализам детаља, па тако реалистично „испричани” - постају овде литерарноестетски функционални, те више не ометају укупно реалистичко усмерење биографске нарације, него учествују у врхунском стилском утиску, који једино оно, по Поповићевом мишљењу, може да произведе. 
Утолико завршну фазу историјскокритичке анализе код Павла Поповића испуњава поново естетичка критика, на основу чијег је почетног суда неко дело уопште вредновано као књижевно и подобно за књижевноисторијско испитивање. Она напокон односи превагу над свим у међувремену обављеним критичким радњама, тиме што образује коначну оцену испитиваног дела и што га њоме уланчава у низ вредновања претходних радова у истом књижевном жанру, успостављајући тако унутар овога нов вредносни поредак, чија се променљивост потом може оценити као градација, стагнација или декаденција у развоју његових унутрашњих могућности. А у случају старе српске биографије, по Поповићевом суду, развијане су као за њу највредније и најрепрезентативније пре свега њене специфичне реалистичке потенције које је још у самом њеном зачетку као такве открио, те истакао св. Сава. Тако естетичка критика сасвим природно прелази у критику момента у традицији једног књижевног рода или врсте, тј. у генеричку критику (Лома 1998: 77, 83-86).

Тиме се оправдава подела Поповићевог прегледа наше старе књижевности по жанровима, утолико више што се њоме увек истиче највише жанровско постигнуће једног писца као меродавно за његову укупну литерарноисторијску позицију, па се његова индивидуалност и биографски представља у оквиру тог генеричког низа, што ће постати сасвим видљиво у приказу дубровачке књижевности. У своме Прегледу Поповић је српску средњовековну литературу одредио као својствену књижевноповесну епоху управо њеним врхунским постигнућем у жанру биографије која се за њу специфичним реализмом издваја из хагиографског рода византијске књижевности.

У првој половини 14. века архиепископ Данило Други написао је Животе краљева и архиепископа српских, а после његове смрти то су дело наставили непознати писци, тако да се не зна колико их је било и шта су све написали. Тај биографски зборник обухвата најпре животописе краљева Уроша и Драгутина, затим краљице Јелене и најобимнију у целој збирци биографију краља Милутина, у којој има „највише историјског причања”, док су претходне две „чисто хагиографски списи” (Исто: 30-31). Следећи је Живот краља Стефана Дечанског, готово исте величине и исте историчности као претходни, који су, свакако, писали Данилови настављачи „врло добро, стварно, с пуно реалнога и живописнога”, без икаквих „примера и изрека из Библије да заустављају причање и развлаче дело, као што је то случај с пређашњим биографијама Данилова зборника" (Исто: 31). Краљевске животописе закључује Душанов само укратко с обзиром на прве године његове владавине (Исто: 31-32).

„Биографије архиепископа и патријарха мање су и неважније. Оне су махом нестварне и празне”, што се, по свему судећи, односи на „чудеса” која износе. Живот архиепископа Данила (Другог), зачетника овог биографског зборника писао је неки његов ученик такође „с пуно реалнога и живописнога", тако да ова биографија заједно са оном посвећеном Стефану Дечанском чини „најбољи део” ове збирке. „Причање” самога Данила, за разлику од приповедања настављача̂, следи Доментијаново, те је „махом задржавано 
фразама, примерима и изрекама библијским, и развучено", али је и боље од свог узора, будући да има „више историјске садржине” (Исто: 32).

Тако српска средњовековна биографија након досегнућа свог реалистичког врхунца у Теодосијевом Животу св. Саве, унеколико доживљава декаденцију у Даниловом библијском маниризму који следи Доментијанов стил, али, за разлику од овога, ипак у сасвим извесној мери чува достигнућа реалистичког историјског приказа који је на самом почетку биографског књижевног жанра код нас утемељио његов први писац св. Сава, да би након Данила његови настављачи углавном стилски чисто заступали предато им наслеђе реализма.

Плодан писац већином у „руској и бугарској рецензији” старословенскога, написавши у српској Живот св. Петке, Григорије Цамблак је на самом измаку 14. столећа наставио традицију животописа у српској средњовековној књижевности. Пригодно је светитељкино житије проширио на пренос њених моштију у Србију. Као дечански монах написао је и Службу Стефану Дечанском, па затим, у првом десетлећу 15. века, и житије овог светог краља, слично начину на који је писано оно из Данилова зборника, само са више „чудеса” и „неких епизода”, чиме појачава хагиографски наспрам тамошњем историјском утиску, те „нарочито истиче врлине” и мучеништво животописанога лика. Како је и у овом делу „причање врло живо и китњасто”, оно спада „међу најбоља дела наше биографске књижевности”, чиме истрајава у близини Теодосијевом врхунцу (Исто: 32-33).

По пропасти бугарске државе 1393. године, као и пре њега Цамблак, долази у Србију Константин, назван Филозофом због своје учености, да би при двору деспота Стефана Лазаревића развио широку књижевну делатност. За живота овога владара извршио је својим делом $O$ правопису реформу књижевног језика. А након деспотове смрти написао је Стефанов животопис, који је „сасвим друкчији” од претходних старих српских биографија. „Најближе су му биографије Милутина и Дечанског у Данилову зборнику”. У ово дело улазе „многе историјске појединости, у њему су честа хронолошка дата.” „Оно је већма историјско, а мање хагиографско”, будући да почивши деспот није био проглашен за свеца. Поред деспотове судбине оно износи такође и њене историјске околности у „широким и засебним сликама”, а које се тичу „околних народа”, „нарочито Турака”. То све чини да ово Константиново - једно од три најобимнија дела старе биографске књижевности, поред Доментијановог и Теодосијевог о св. Сави - „има највећма историјски карактер у свом роду”, мада ни оно „не оскудева у чудесима”, чиме поприма „хагиографску” црту. „Причање је каткад врло живо, стварно и добро”, мада је „ова биографија писана мало тежим језиком, стилом гдегде сувише књижевним и тамним”: „у њој има речи и примера из Библије”, али такође из хеленске антике (Исто: 33-34). Поповић је и овом приликом успео да индивидуализује пишчев лични допринос развоју жанра. Константинова ученост је уједно подстицајни и реметилачки чинилац за историјски реалистичку нарацију. Она је подупире историјским и хронолошким подацима, али је и омета освртима познаваоца Библије и античког хеленства. Ипак се, у целини гледано, 
ова биографија приближава историографији и њој специфичној реторици, а удаљава од хагиографије.

У 16. веку Поповић истиче потпуни недостатак биографских списа, те средином следећег столећа постојање само једног таквог текста, а то је Живот ияара Уроша од Пајсија, патријарха Пећке патријаршије (обновљене 1557). Он је такође написао и службу овом светом владару. Она биографија се враћа хагиографском приступу по својој краткоћи, те већој пажњи према постхумној судбини светитеља, уз живописно приповедање које врхуни у лепоти наивне непосредности описа (Исто: 34-35). Утолико патријарх Пајсије остаје веран традицији реалистичке живописности старих српских биографија уз сасвим известан повратак овог жанра свом хагиографском исходишту, чиме се затвара његов развојни круг, започет реалистичком и историјском еманципацијом од онога хагиографски мистичног и легендарног, за шта Поповић није имао довољно разумевања (Лома 1998: 75-76, 82, 83, 86).

Напокон стара српска биографија прелази у жанр похвале владарима и архиепископима који може нагињати на страну пуког реторског или на страну историјски, односно биографски аргументованог хваљења. Поповић посебно истиче Похвалу кнезу Лазару, коју је монахиња Јефимија, удовица деспота Угљеше, написала крајем 14. века - као достојну златног веза на Лазаревом покрову у Раваници, а која представља кратку молитву овом владалачком мученику да код Бога измоли спасење злосрећне Србије. Друге, касније похвале „умногоме допуњују наше старе биографије, дајући нарочито вести о владаоцима и архиепископима после Немањића, о којима биографије не говоре ништа. Њима се често не зна писац, ни време у којем су постале" (Исто: 35$)$.

Старе српске биографије се код Павла Поповића још јасније појављују у својој посебности као хибридни књижевни род који спада уједно и у хагиографску, и у историографску литературу, али се у српској књижевности образује и засебно на показан својствен, превасходно историјско-реалистички начин, тако да њему припадајући списи „чине и главне споменике наше прошлости" (Исто). У српској историографији хронике су преводи византијских дела, а из њих су се развили хронографи, „словенске компилације истога рода”, „само са допунама словенске или југословенске историје”, „руске, бугарске и српске”. „Градиво за српску историју узимано је из старих српских биографија" (Исто: 36-37), па је тако дотична историографска врста генетички везана за најважнији књижевни жанр у српској књижевној старини, онај биографски.

У хронографима је, као и у хроникама, „главна светска историја, општи део" (Исто: 38), и то од Постања, преко јеврејске и римске до византијске повести (Исто: 36), ,а узгредна је српска историја, посебни део; у летописима је обратно, и чак општег дела каткад нема никако". У њима општи део „црпе градиво, вероватно, из византијских хроника”; посебни пак „из старих српских биографија, похвала" и разноврсних ,записа" (Исто: 38), чиме се и ова историографска врста својим пореклом везује за биографски жанр као књижевно највреднији у старој српској литератури. 
А то је поново случај и са родословима, будући да „генеалогија Немањића” из Живота деспота Стефана од Константина Филозофа чини „основ нашим родословима”. Троношки и Пећки родослов, „представљају исту редакцију” из друге половине 18. века и „најлепше и најзанимљивије” „међу свима досад поменутим историјским списима”, будући да „излажу и све, па и најситније догађаје тога времена, дају описе места, карактеришу личности, причају потанко битке, уплићу разне анегдоте, па чак и полемишу са писцима из којих црпу вести" (Исто: 40).

А ово су поново критеријуми већ познатог Поповићевог естетичко-критичког става, његовог историјско-реалистичког укуса, коме је он ставио у службу своју историјску критику, пре свега усмерену ка својственим књижевноповесним циљевима, као што су то понајпре утврђивање норме књижевног језика, те у оквирима њеног трајања одређивање континуитета специфично литерарних генеричких традиција и њихових узајамних генетичких веза. Отуда и продужење излагања старе, у својој основи средњовековне српске књижевности у њеним крајњим дометима све до краја 18. столећа. Наиме, Троношки родослов Поповић датира на 1791. годину (Исто).

У сличном смислу је схватљиво и везивање за стару српску књижевност и Славено-сербске хронике грофа Ђорђа Бранковића из „последњих година 17.” и „првих година 18. века”, коју пак Поповић издваја у подврсту „посебних списа” у оквиру оних историографских, будући да она користи далеко разноврсније изворе од хроника и хронографа у српској књижевној традицији. У истој недовољно жанровски спецификованој групацији историјских радова Поповић помиње још и онај под називом Косовски бој, написан 1714/1715. године. У њему се ова битка описује „по народној традицији, као и у Троношком и Пећком родослову; има каткад и стихова, као и у ових”; „само је овде причање шире”, „потпуније и лепше, као и што су личности боље и изразитије окарактерисане, и ситуације драматичније представљене” (Исто: 41).

Том оценом истиче Поповић поменути спис као врхунски домет у књижевном роду старе српске историјске прозе након апсолутног врхунца укупне старе српске књижевности у биографији, према коме је оно повесно дело само релативно књижевно постигнуће у оквиру својих генеричких ограничења. Оно не зависи од учене и писмене биографске, односно историографске традиције, већ од усмене, народне, тако да представља спону ка новој епохи у развоју српске књижевности, ка народној књижевности, коју Поповић означава пре свега као изворно сублитерарни ток. Будући да је „дубоко под књижевним слојевима српског народа и ван општег тока писане књижевности", он је у своме исходишту невидљив, те неодредљив по њему, тако да се не може знати ни тачан почетак те ,усмене” књижевности, као ни њени творци. Она је у своме постању утолико ,анонимна” (Исто: 42), све док превасходно Вуковом делатношћу коначно не буде унета у писмену књижевну традицију (Исто: 43,69$)$ и једним делом ауторизована по најбољим певачима од којих је Вук записивао песме. 
Усмену књижевну традицију на говорном народном језику, баш зато што је унутар ње немогуће успоставити јасне хронолошке релације, баш зато што се њена дела углавном не могу ни ауторизовати, ни датирати, а с обзиром на њихову језичку блискост дубровачкој књижевности и на њихове извесне одјеке у овој још од 15. века (Исто: 43) - поставља Поповић између старе српске (од краја 12. до њених последњих одјека у 18. веку) и три столећа литературе Дубровачке Републике (од краја 15. до краја 18. века) (Исто: 86), и то чини превасходно како би уметничкоисторијски тачно позиционирао претходно остварење књижевно врхунски вредне народне поезије и прозе (Исто: 3, 69-70). У односу на нову - дубровачка се показује као „средња” (Исто: 5,86$)$ књижевност која је, попут старе и нове, такође уметничка и писмена насупрот оној народној и усменој: „Дубровнику је било суђено да прихвати српску књижевност у тренутку кад је стара ћириловска књижевност почела падати, и да је одржи, док се нова књижевност не почне рађати”. Но стара српска књижевност је остала без икаквог утицаја на ову средњу, односно дубровачку, која је „била сасвим друкчија” од ње (Исто: 86).

Дубровачки литерарни развој је започео под утицајем италијанске ренесансе и са учешћем у њему свих образованих, тј. „културних сталежа” Републике. Италијански књижевни уплив ће остати трајно обележје ове литературе, која је писана латиницом и по италијанском правопису (Исто: 86-87). „Као и остале, и дубровачка књижевност прелажена је по родовима (и вековима)”, с тим што је у овом случају било могуће путем много прецизнијег датирања готово у потпуности извести како периодизацију по столећима, тако и унутар ње поделу укупног епохалног развоја на засебне традиције књижевних родова и врста. Наиме, књижевни историограф је за ову литературу располагао обиљем хронолошких података, а она је такође у континуитету обухватала традиције различитих жанрова, пре свега преузетих из италијанске књижевности. Све то је омогућавало аутору да по вековима као уједно културним и књижевним епохама прати „општи ток дубровачке књижевности”, и то у свој његовој разуђености динамиком органског „развоја” различитих генеричких низова у њиховом узајамном дејству, приликом кога се образују књижевне „школе и правци” под плодним или јаловим страним утицајима. При томе је такође од значаја постало и утврђивање потпуног изостанка неких од жанрова у одређеним раздобљима (Исто: 4-5).

Стара српска књижевност, без непосредног утицаја на народну (Исто: 42 ) и средњу, дубровачку (Исто: 86), а и на нову књижевност код Срба (Поповић 1999б: 47, 50, 107, 122, 135, 139-140), остаје при Поповићевом посматрању њене судбине у југословенским оквирима такође суштински изолована и од средњовековне литературе оних Словена на југу Европе који су се национално развијали ван утицаја византијске културе и Цариградске патријаршије (Поповић 1999а: 86). То су народи с којима се пропагирала државна заједница након Првог светског рата: Хрвати и Словенци. Тој пропаганди је својом основном концепцијом у видљивој мери излазила у сусрет и Поповићева Југословенска књижевност (Николић 2009), „предата у штампу децембра 1917”, а штампана „почетком 1918. у Кембриџу, у Енглеској” (Љу- 
бинковић 1999: 207, 208), у години у којој су с јесени окончана ратна дејства и проглашена Краљевина Срба, Хрвата и Словенаца.

Поповић се, као и у своме Прегледу српске књижевности, послужио филолошким критеријумом приликом издвајања југословенске средњовековне литературе из старе словенске, а на основу српске рецензије старословенског језика, какав су Ћирило и Методије увели у књижевну, односно богослужбену употребу, с тим што је сада ову рецензију додатно идентификовао и као хрватску (Поповић 1999б: 1-2), утврдивши различитост писама, глагољичног код Хрвата и ћириличног код Срба, али такође и вредносно првенство српске над истовременом хрватском литературом (Исто: 4), које заснива пре свега на оригиналном историјском реализму старих српских биографија (Исто: 5-7, 10). Словеначка књижевност је у приказу овога доба остала сасвим по страни, већ на основу језичке разлике, као и малог броја сачуваних сведочанстава (Исто: 3,11$)$. Хрватска и словеначка писменост су, насупрот српској, ометене у своме развоју, зато што је црквена служба на старословенском језику код ових јужних Словена потискивана. У Словенији је она „ишчезла убрзо”, због чега у средњем веку ту није ни било основа за образовање домаће књижевности. А у Хрватској, где је словенска литургија била „у мањој мери” допуштена, то је у овоме раздобљу омогућило известан књижевни развој, ипак знатно мање богат него истовремени у Србији, где ће се развити „најбогатија" средњовековна књижевност код будућих Југословена. То се збило кроз зачетнички додир са старословенском литературом, негованом већ три века у Македонији и Бугарској и „произашлом из словенске службе”, која је била и српска. Наиме, до тог културног контакта је дошло услед ширења поседа великог жупана Стефана Немање ка унутрашњости Балкана (Исто: 151-152). Управо својим оригиналним процватом у биографском жанру стара српска књижевност се одликује међу свим словенским књижевностима, у којима „нема сличних дела” (Исто: 155). Тако се и Поповићев преглед југословенске књижевности у средњем веку затвара естетском критиком, којом је и започео бављење овом литературом као лепом уметношћу од самог уметничког утиска који буди њено непосредно читање, да би се преко историјске критике средине и тренутка, односно генеричке критике традиције - поново вратио естетичком просуђивању. Утолико је код Павла Поповића овде јасно назначена градација литерарнокритичких поступака кроз њихову функционалну повезаност и сврсисходност, која се завршава у коначном естеском суду и примени њиме успостављене хијерархије вредности на књижевноисторијске прилике. 


\section{ЛИТЕРАТУРА}

Љубинковић 1999: Н. Љубинковић, „Поповићева синтетичка сагледавања југословенске (југословенских) књижевности у виђењу и вредновању савремене стручне критике”, стр. 205-224, у: Павле Поповић, Сабрана дела, књ. 9: Југословенска књижевност, приредио Ненад Љубинковић, Завод за уџбенике и наставна средства, Београд.

Лома 1998: M. Loma, „Književnoistorijski postupak Pavla Popovića u primeni na srpsku srednjovekovnu književnost”, str. 51-87, u: PH2, Godišnjak za poetička i hermeneutička istraživanja, Beograd.

Лома 1994: М. Лома, Песник и књижевна историја, Проблем приказивања песника у историјама немачке књижевности, Издавачка књижарница Зорана Стојановића Сремски Карловци, Нови Сад.

Милосављевић 1994: П. Милосављевић, „Књижевнотеоријска мисао Павла Поповића", стр. 339-351, у: Зборник Матице српске за књижевност и језик, књ. 57, св. 2.

Николић 2009: Н. Николић, „Концепције српске и југословенске књижевности Павла Поповића", стр. 267-295, у: Зборник Матице српске за књижевност и језик, књ. 42, св. 1-3.

Павловић 1959: Д. Павловић, „Павле Поповић као научник и књижевни историчар", стр. 197-208, у: Прилози за књижевност, језик, историју и фолклор, књ. 25, св. 3-4.

Пантић 1999: М. Пантић, „Преглед српске књижевности Павла Поповића”, стр. 227-237, у: Павле Поповић, Сабрана дела, књ. 1: Преглед српске къижевности, приредио Мирослав Пантић, Завод за уџбенике и наставна средства, Београд.

Поповић 1999а: П. Поповић, Сабрана дела, књ. 1: Преглед српске књижевности, приредио Мирослав Пантић, Завод за уџбенике и наставна средства, Београд.

Поповић 1999б: П. Поповић, Сабрана дела, књ. 9: Југословенска књижевност, приредио Ненад Љубинковић, Завод за уџбенике и наставна средства, Београд.

Скерлић 2006: Ј. Скерлић, Историја нове српске књижевности, приредио Јован Пејчић, Београд: Завод за уџбенике.

Meyer 1916: R. M. Meyer, Die deutsche Literatur bis zum Beginn des 19. Jahrhunderts, hrsg. v. Otto Pniower, Berlin. 
Miodrag Loma

\section{PAVLE POPOVIĆS PERIODISIERUNGEN DER SERBISCHEN UND JUGOSLAWISCHEN LITERATUR MIT BESONDERER RÜCKSICHT AUF SEINE BESTIMMUNG DER ALTEN SERBISCHEN LITERATUR}

\section{(Zusammenfassung)}

In der vorliegenden Arbeit wird „die historische Kritik” des hervorragenden serbischen Literaturhistorikers Pavle Popović (1868-1939) als methodologischer Ausgangspunkt für seine Gliederung der serbischen und jugoslawischen Literaturgeschichte und vor allem für seine Bestimmung der alten serbischen Dichtung als ihrer Anfangsphase betrachtet. Das unmittelbare Ziel der Betrachtung besteht darin, die Glaubwürdigkeit von Popovićs Periodisierung der alten serbischen Literatur von dem literaturästhetischen Standpunkt aus zu prüfen, der für eine Formgeschichte der Dichtung grundlegend war. Insofern beschäftigt sich die Arbeit besonders mit Popovićs generischer Einordung der altserbischen Literaturwerke. 